\title{
ВЕДУЩЕЙ КУЛЬТУРЕ ДАГЕСТАНА - КАПУСТЕ ОЗИМОЙ - БОЛЬШЕ ВНИМАНИЯ
}

\author{
Велижанов Н.М. - кандидат С.-х. наук, С.н.С. \\ Фгну Дагестанская селекционная опытная станция \\ виноградарства и овощеводства \\ 368600, Республика Дагестан, г. Дербент, ул. Вавилова, 9
}

\begin{abstract}
Сухие субтропики Южного Дагестана - родина капусты озимой белокочанной, одной из основных кульмур озимого овощеводсмва. здесь издавна занимаются ее возделыванием. Основой возникновения этого направления явился сорт Парижская рыночная. Сорт скороспелый, усмойчивый к растрескиванию в условиях зимней кульмуры, однако не получивиий больмого распространения ввиду малой урожайности. Поэмому возникла необходимость улучшения и расиирения сортимента озимой капусты для данного региона.
\end{abstract}

Ключевые слова: капуста озимая, сорта

абота по селекции сортов озимой капусты на Дагестанской СОС виноградарства и овощеводства была начата еще в 1966 году. В настоящее время приоритетное направление в селекционной работе с капустой белокочанной в озимой культуре - получение сортов с гарантированной урожайностью ранней капусты не менее 30 т/га, пригодных для выращивания в промышленном производстве и личных подсобных хозяйствах. При этом для получения стабильного урожая нужны не только высокопродуктивные сорта, но и благоприятные условия внешней среды, то есть необходимо сочетание необходимых условий.

Климат республики отличается сухостью и высокими летними температурами, тёплой и влажной осенью, что благоприятно сказывается на росте, развитии и перезимовке капусты в озимой культуре. В низменной зоне Дагестана продолжительность посевного периода имеет решающее значение для нормального развития озимых овощных культур. Для озимой капусты этот показатель важен в апреле и июне; относительная влажность воздуха имеет существенное значение для культуры в апреле - мае.

В пределах ареала культуры селекционеру важно знать, какие результаты по конкретному сорту можно получить в благоприятных условиях определённой климатической зоны. Теоретически, пользуясь шкалой изменчивости признаков и зная для сорта конкретные значения $\mathrm{X}$, а также стандартное отклонение, можно прогнозировать возможную урожайность.

Селекционная работа с озимой капустой на опытной станции направлена на создание более урожайных сортов с плотными кочанами, устойчивых к растрескиванию, цветушности, низким температурам и наиболее распространённым заболеваниям. Для этого закладываются питомники по полной схеме селекционного процесса, образцы оцениваются на фоне стандарта по ком- плексу хозяйственно ценных признаков; применяются аналитический (массовый и индивидуальный отборы) и синтетический (межсортовая, сортолинейная и межлинейная гибридизация с последующим отбором) методы селекции, используются местные сорта, а также отечественного и зарубежного производства.

Значительному ускорению селекционного процесса способствует плодотворное сотрудничество с ВНИИР им. Н.И. Вавилова, который представляет сортообразцы из стран Западной Европы, Скандинавских стран, ЮгоВосточной Азии.

В 2002-2008 годах на основании комплексного изучения 48 образцов капусты из мировой коллекции ВНИИР им. Н.И. Вавилова, собранных из 16 стран, были выделены источники высокой продуктивности, адаптивности, питательной ценности и зимостойкости: Нагаока Харухикари, $F_{1}$ Генри, Секинс (Япония), Спико А (Нидерланды).

За последние 5 лет нами районированы и внесены в Госреестр селекционных достижений, допущенных к использованию в РФ, два сорта: Офелия и Горянка - 5. В 2004 году на них получены авторские свидетельства.

Горянка-5 - раннеспелый сорт. От всходов до первого сбора урожая - 230 суток. Характеризуется дружной отдачей урожая. Урожайность - 31,2 т/га. Кочаны конусовидной формы, диаметром 15 см, средняя масса кочана - 1,4 кг; товарность урожая - 98\%.

Офелия - раннеспелый сорт. От всходов до сбора урожая - 230 суток. Средняя масса кочана 1,5 кг, товарность урожая 99\%. Кочаны округлой формы, диаметром $16 \mathrm{~cm}$.

В настоящее время проходит сортоиспытание новый сорт Лезгинка.

Выращивание этих сортов позволит значительно расширить существующий сортимент капусты и сроки её поступления к потребителю. 